\title{
Efektivitas Model Pembelajaran Accelerated Learning Pada Mata Pelajaran Teknologi Dasar Otomotif
}

\section{Silvermen ${ }^{1 *}$, Syahril ${ }^{2}$, Wakhinuddin ${ }^{3}$}

${ }^{123}$ Universitas Negeri Padang, Padang, Indonesia

*e-mail: s1lvermen.boil1979@gmail.com

\begin{abstract}
Abstrak
Pembelajaran yang masih berpusat pada guru yang berdampak terhadap berkurangnya minat belajar siswa yang berdampak terhadap hasil belajar. Tujuan penelitian ini untuk mengetahui peningkatan aktivitas belajar dan hasil belajar siswa. Penelitian ini adalah penelitian tindakan kelas. Subjek penelitian adalah siswa kelas $X$ TKR dengan jumlah 22 siswa. Instrumen penelitian menggunakan lembaran observasi untuk aktivitas belajar dan soal tes untuk hasil belajar. Data hasil belajar dianalisis dengan menggunakan teknik deskriptif ketuntasan individu dan klasikal, sedangkan data aktivitas belajar dianalisis dengan teknik persentase. Hasil analisis data menunjukkan bahwa: (1) Model pembelajaran Accelerated Learning dapat meningkatkan hasil belajar siswa dilihat dari ketuntasan klasikal sebesar $54,5 \%$ pada siklus I dan $86,4 \%$ pada siklus II dengan peningkatan nilai rata-rata sebesar 12,6 dari 2 siklus; (2) peningkatan aktivitas belajar sebesar 21,9\%. pada siklus I diperoleh sebesar $59,1 \%$ dalam kategori cukup dan pada siklus II sebesar $80,79 \%$ dalam kategori baik. Berdasarkan hasil penelitian, dapat disimpulkan bahwa model pembelajaran accelerated learning dapat meningkatkan aktivitas dan hasil belajar siswa.
\end{abstract}

Kata kunci: accelerated learning, aktivitas dan hasil belajar

\begin{abstract}
Learning that is still teacher-centered has an impact on the reduced interest in student learning which has an impact on learning outcomes. The research objective was to determine the increase in learning activities and student learning outcomes. This research is a classroom action research. The research subjects were students of class $X$ TKR with a total of 22 students. The research instrument uses observation sheets for learning activities and test questions for learning outcomes. The learning outcome data were analyzed using descriptive individual and classical completeness techniques, while the learning activity data were analyzed using the proportion technique. The results of data analysis show that: (1) Accelerated Learning model can improve student learning outcomes seen from classical completeness by $54.5 \%$ in cycle I and $86.4 \%$ in cycle II with an increase in the average value of 12.6 from 2 cycle; (2) an increase in activity by $21.9 \%$. in the first cycle it was obtained $59.1 \%$ in the sufficient category and in the second cycle it was $80.79 \%$ in the good category. Based on the research results, it can be seen that the learning accelerated learning model can increase student activity and learning outcomes.
\end{abstract}

Keywords: accelerated learning, activities and learning outcomes

\section{Pendahuluan}

Pendidikan sangat diperlukan untuk menghasilkan manusia yang terampil, produktif, inisiatif, dan kreatif. Penguasaan ilmu pengetahuan dan teknologi merupakan unsur pembentukan kemajuan dan kemandirian bangsa yang dapat tumbuh dan berkembang melalui pendidikan. Oleh karena itu, pendidikan merupakan salah satu

\footnotetext{
${ }^{*}$ Corresponding author.

Received 30 Januari 2021; Accepted 1 Maret 2021; Available online 8 April 2021 (c) 2021 MI All Rights Reserved
} 
sektor pembangunan yang paling utama untuk menghasilkan manusia terampil dan berdaya saing. Untuk mewujudkan semua itu maka pemerintah mendirikan sekolah menengah yang bernuasa kejuruan atau yang sering kita sebut dengan SMK. Untuk menghasilkan manusia yang terampil dan berdaya saing, guru dituntut untuk mampu menerapkan model pembelajaran yang sesuai dengan karakteristik materi pelajaran. Hal ini dilakukan untuk meningkatkan efektifitas pembelajaran dikelas. Suatu model pembelajaran mempunyai spesifikasi tersendiri, artinya model yang cocok untuk suatu materi tertentu belum tentu cocok digunakan pada materi yang lain. Model pembelajaran yang diterapkan diharapkan tidak hanya sesuai dengan materi saja, melainkan juga mempu menjadikan siswa aktif terlibat dalam proses kegiatan belajar mengajar semaksimal mungkin yang berdampak pada hasil belajar yang maksimal.

Fakta dilapangan menunjukan hasil yang bertolak belakang. Berdasarkan observasi, khususnya pada mata pelajaran Teknologi dasar Otomotif ditemukan sebagian besar siswa memiliki pamahaman konsep yang rendah dan banyak siswa yang masih beranggapan bahwa Teknologi dasar Otomotif merupakan pelajaran teoritis yang sulit dan membosankan. Selain itu, proses pembelajaran selama ini terlalu dipengaruhi pandangan bahwa siswa Teknik Kendaraan Ringan adalah alat yang siap pakai, pandangan ini mendorong guru bersikap cenderung memberitahu konsep, sifat maupun teori serta cara penggunaannya. Pembelajaran menjadi terpusat pada guru, siswa kurang dapat mengembangkan dan mengekpresikan potensi diri. Hasil belajar siswa kelas X jurusan Teknik Kendaraan Ringan (TKR) pada mata pelajaran Teknologi Dasar Otomotif menemukan hanya terdapat $54,5 \%$ siswa dari 22 orang siswa yang memperoleh hasil belajar diatas KKM. Hal ini didukung juga oleh penelitian Wardana \& Sagoro (2019) yang menemukan bahwa $87,5 \%$ siswa tidak mencapai hasil belajar diatas KKM. Rata-rata nilai hanya menunjukan 54,17. Penelitian Lestiawan, F., \& Johan, (2018) menyebutkan bahwa hasil belajar dasar-dasar pemesinan siswa di sekolah $X$ terbilang masih rendah. Sebanyak $50 \%$ siswa belum mencapai KKM yang seharusnya. Jumlah siswa yang mencapai KKM pada ulangan harian juga hanya mencapai $50 \%$. Siswa cenderung tidak aktif didalam kegaiatan pembelajaran dikelas. Rahmat et al., (2018) dalam penelitiannya menemukan dari total 128 siswa kelas X Teknik Kendaraan Ringan, sebanyak $57,82 \%$ siswa atau 74 siswa belum mencapai KKM yang telah ditetapkan. Sementara itu, $42,18 \%$ siswa atau 54 siswa telah mencapai KKM. Berdasarkan pengamatan yang dilakukan oleh peneliti, proses pembelajaran kurang efektif dan kondusif, dengan indikasi siswa terlihat bosan, keluar masuk kelas, beberapa siswa tidak memperhatikan guru ketika proses pembelajaran berlangsung.

Hasil observasi dan beberapa fakta penelitian terdahulu menunjukan bahwa hasil belajar mata pelajaran otomotif masih tergolong rendah. Jika hal ini tetap dibiarkan maka akan berdampak pada buruknya kwalitas lulusan SMK. Selain itu, harapan bahwa lulusan SMK akan siap kerja tidak akan tercapai. Untuk itu perlu adanya perhatian khusu dan serius terhadap permasalahan ini. Hasil belajar siswa dipengaruhi oleh beberapa faktor. Salah satunya adalah model pembelajaran yang digunakan oleh guru. Beberapa penelitian terdahulu menunjukan bahwa model pembelajaran berpengaruh signifikan terhadap hasil belajar siswa (Bahari et al., 2018; Sawawa et al., 2018; Widani et al., 2019; Witari et al., 2018).

Berkaitan dengan hal tersebut, model pembelajaran yang diterapkan guru hendaknya merupakan model pembelajaran yang dapat memberikan kesempatan kepada siswa untuk berpartisipasi aktif, baik secara fisik maupun mental dalam kegiatan pembelajaran dikelas. Model Accelerated Learning diasumsikan sesuai untuk pembelajaran yang seperti itu. Model Accelerated Learning merupakan pembelajaran yang membuat siswa termotivasi, membuat belajar lebih bermakna dengan menciptakan suasana belajar yang menyenangkan serta melibatkan langsung baik fisik maupun mental dalam proses pembelajaran (Kusuma \& Ramadoni, 2020). Accelerated Learning tidak hanya memfokuskan pada apa yang dipelajari siswa, tetapi mengajarkan siswa bagaimana cara belajar dan bagaimana cara berpikir. 
Accelerated Learning merupakan proses pembelajaran dengan menggunakan teknik-teknik belajar yang sesuai dengan gaya belajar masing-masing individu (Kusuma \& Ramadoni, 2020; Syamsi et al., 2016). Model Accelerated Learning adalah suatu model mengajar yang memungkinkan siswa dapat belajar secara alamiah dengan menggunakan teknik- teknik belajar yang cocok dengan karakter dirinya sehingga mereka akan merasakan bahwa belajar itu menyenangkan, efektif, dan cepat. Dalam model pembelajaran ini, guru harus merancang berbagai aktivitas yang dapat menggabungkan berbagai jenis gaya belajar siswa (Kusuma \& Ramadoni, 2020; Subeni, 2018; Sucipto et al., 2018). Strategi cara belajar cepat dalam Accelerated Learning merupakan paduan dari metode-metode pembelajaran yang dibagi menjadi enam langkah dasar. Keenam langkah dasar itu dapat diingat dengan mudah yaitu dengan menggunakan singkatan M-A-S-T-E-R. $M$ adalah Motivating Your Mind (Memotivasi Pikiran), A adalah Acquiring The Information (Memperoleh Informasi), S adalah Searching out the Meaning (Menyelidiki Makna), T adalah Triggering the Memory (Memicu Ingatan), E adalah Exhibiting What You Know (Memamerkan Apa yang Anda Ketahui), R adalah Reflecting (Merefleksikan) (Cahyani et al., 2015; Kusuma \& Ramadoni, 2020; Putra \& Linda, 2016)

Penelitian terdahulu menunjukan model pembelajaran Accelerated Learning efektif untuk meningkatkan hasil belajar siswa. Penelitian yang dilakukan oleh Kusuma \& Ramadoni (2020) menemukan bahwa model accelerated learning efektif meningkatkan hasil belajar matematikan siswa. Penelitian ini dilakukan dengan desain penelitian factorial $3 \times 3$. Hasil penelitian menunjukan bahwa model pembelajaran accelerated learning dapat meningkatkan kemampuan berpikir dan komunikasi matematika. Hasil ini semakin meningkat ketika dipadukan dengan model pembelajaran berbasis masalah. Siregar (2019) dalam penelitiannya menemukan hasil bahwa model pembelajaran accelerated learning dapat meningkatkan ketertarikan sisa terhadap soalsoal matematika. Ketertarikan ini menumbuhkan motvasi dan intensitas siswa dalam berlatih soal-soal matematika. Hal ini berdampak pada hasil belajar matematika yang semakin tinggi. Subeni (2018) menggunakan model accelerated learning untuk untuk meningkatkan motivasi belajar siswa dalam mata pelajaran Fisika. Hasil penilitian menunjukan bahwa motivasi belajar fisika siswa sebelum diterapkan konsep accelerated teaching model adalah 116.67 dan setelah diterapkan konsep accelerated teaching model motivasi belajar fisika siswa adalah 140.97. Hal ini menunjukkan bahwa terdapat peningkatan yang signifikan antara motivasi belajar fisika. Peneltian terdahulu menerapkan model pembelajaran accelerated learning pada sekolah menengah atas dengan mata pelajaran teori matemtaika dan ilmu pengetahuan alam. Sedangkan penelitian ini menerapkan model pembelajaran accelerated learning untuk siswa sekolah menengah kejuruan dengan matapelajaran teknologi dasar otomotif. Penelitian ini dilakukan dengan model tindakan kelas yang berbeda debngan penelitian terdahulu yang sebagian besar dilakukan dengan metode eksperimen.

Tujuan peneiltian ini adalah untuk mengetahui efektivitas model pembelajaran accelerated learning pada mata pelajaran teknologi dasar otomotif. Secara pedagogis, penelitian ini berimplikasi pada meningkatnya pembelajaran pada mata pelajaran teknologi dasar otomotif. Dengan kualitas pembelajaran yang baik, model dan metode yang sesuai dengan tujuan pembelajaran dan kebutuhan siswa, maka hasil belajar siswa juga dapat meningkat. Melalui hasil penelitian ini diharapkan para praktisi pendidikan khususnya guru teknologi dasar otomotif, dapat segera berhijrah dari model pengajaran yang konvensional yaitu ceramah dan diskusi kepada model pengajaran yang lebih modern dan sesuai dengan kebutuhan siswa.

Secara Penggunaan model pembelajaran accelerated learning dalam penelitian ini diharapkan; (1) dapat meningkatkan pemahaman siswa terhadap materi pembelajaran, (2) memberikan kesempatan kepada siswa terlibat aktif dalam diskusi dan praktikum, (3) mengajak siswa mencari makna atau mengkaitkan materi yang di pelajari dengan situasi 
dunia nyata, (4) mengutamakan bagaimana proses siswa menjadi tahu dan paham tentang konsep tertentu.

\section{Metode}

Penelitian ini menggunakan pendekatan penelitian tindakan kelas (PTK). Sampel dalam penelitian ini adalah kelas X TKR SMK Negeri 1 Kecamatan Suliki semester genap tahun ajaran 2015/2016 yang berjumlah 22 orang.

Penelitian ini dilaksanakan dengan bantuan guru mata pelajaran yang sama sebagai kolaborator atau observer. Penelitian ini berupa siklus-siklus pembelajaran. Siklus dalam penelitian ini terdiri dari empat tahap atau komponen, yaitu: perencanaan, pelaksanaan, pengamatan dan refleksi.

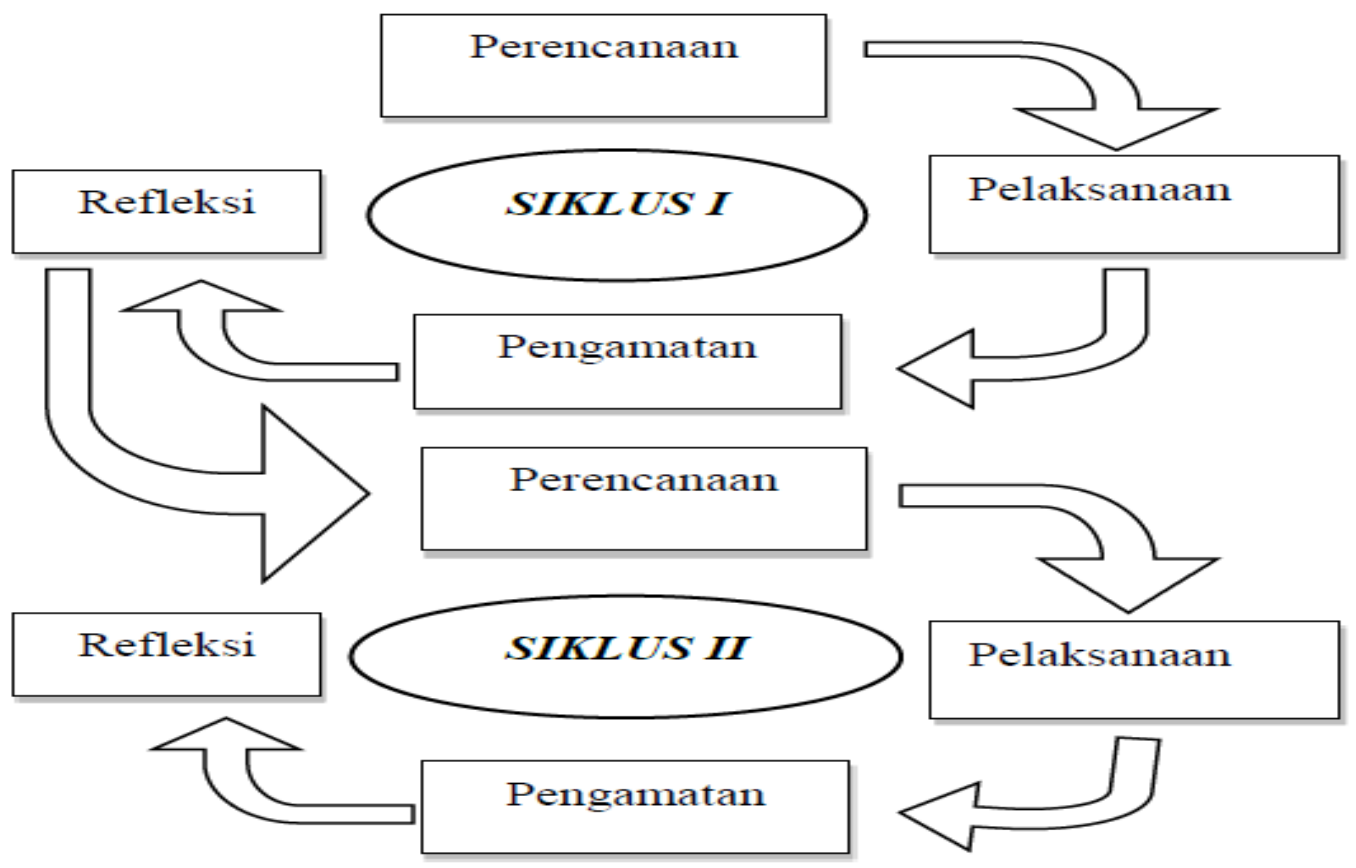

Gambar 1. Desain Penelitian

Sumber: Arikunto (2012:16)

Teknik pengumpulan data dari penelitian ini adalah menggunakan teknik Observasi/pengamatan langsung, Dokumentasi, dan Tes. Sedangkan instrument yang digunakan dalam penelitian ini berupa soal tes dan non tes untuk memperoleh data tentang aktivitas siswa dalam proses pembelajaran dan hasil belajar Teknologi dasar Otomotif. Data hasil belajar siswa diperoleh berdasarkan hasil tes pada setiap akhir siklus, sedangkan data aktivitas belajar diperolah dari lembar aktivitas siswa. Data yang diperoleh tersebut diolah menggunakan metode deskriptif dan persentase. Kategori aktivitas belajar siswa dapat dilihat pada Tabel 1 berikut ini.

Tabel 1. Kriteria Kategori Aktivitas Belajar

\begin{tabular}{cc}
\hline Presentase & Kategori \\
\hline $81 \%-100 \%$ & Baik Sekali \\
$61 \%-80,99 \%$ & Baik \\
$41 \%-60,99 \%$ & Cukup
\end{tabular}


$21 \%-40,99 \%$

$0 \%-20,99 \%$
Kurang

Kurang Sekali

Berdasarkan Tabel 01 di atas, pencapaian aktivitas belajar siswa yang diharapkan pada penelitian ini adalah pada kategori baik ke atas yaitu persentase $61 \%$ keatas karena apabila konsep diri posistif siswa sudah baik, maka pelajaran akan dengan mudah dipahami oleh siswa. Sedangkan Hasil Belajar Siswa diolah dengan menggunakan statistik deskriptif untuk melihat ketuntasan hasil belajar individu sesuai KKM (Kriteria Ketuntasan Minimal) secara klasikal sebesar 80\%.

\section{Hasil dan Pembahasan}

Pada siklus 1 pembelajaran dengan menggunakan model accelerated learning belum berjalan secara optimal. Hal tersebut dapat dilihat dari hasil penelitian yang belum mencapai indikator keberhasilan penelitian. Dimana diperoleh nilai rata-rata hasil belajar sebesar 71,09 dengan ketuntasan klasikal 54,5\%. Dari hasil tes ini dapat diketahui bahwa Ketuntasan Klasikal hasil belajar siswa belum tercapai (minimal $80 \%$ ) seperti yang terlihat pada Gambar berikut ini.

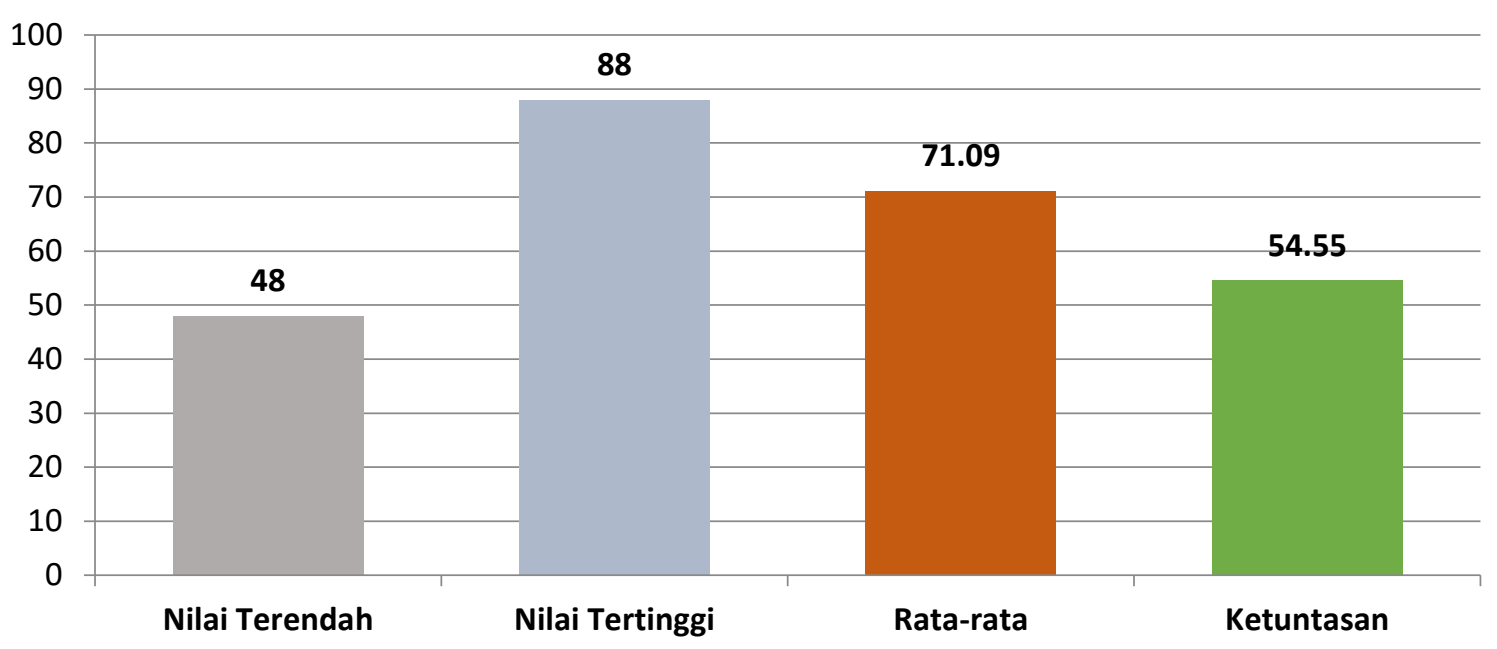

Gambar 02. Diagram Hasil Belajar siswa Siklus 1

Sedangkan untuk persentase pencapaian aktivitas belajar siswa pada siklus I sebesar $51,91 \%$ dalam kategori cukup. Pada siklus II diperoleh hasil evaluasi pengamatan proses pembelajaran yang diamati sebanyak dua kali pertemuan berdasarkan beberapa indikator yang diamati berada dalam kategori baik, yang mana persentasenya sebesar $80,79 \%$ berada pada rentang $61-80,99 \%$.

Sedangkan untuk hasil belajar dari tes yang dilakukan pada akhir siklus II seperti yang ditunjukkan pada Gambar 3 di bawah ini diperoleh sebanyak 19 siswa dari total 22 siswa yang telah mencapai nilai ketuntasan dengan persentase sebesar $86,4 \%$. Sedangkan siswa yang belum tuntas adalah sebanyak 3 orang siswa dengan persentase sebesar 13,6\%. Dari hasil tes ini dapat diketahui bahwa Ketuntasan Klasikal siswa telah tercapai (minimal 80\%) dan tindakan/perlakuan dapat dihentikan pada siklus 2 ini. 


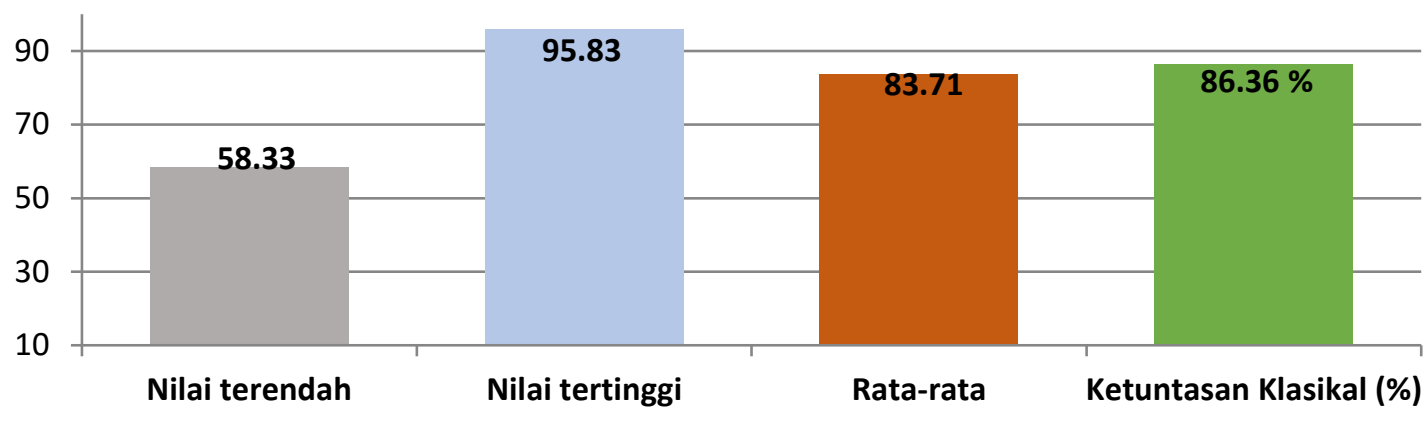

Gambar 3. Hasil belajar siklus 2

Peningkatan hasil belajar siswa dapat diketahui dengan melihat perbandingan hasil belajar pada pasca siklus I dan siklus II. Berdasarkan hasil analisis data penelitian, penggunaan model pembelajaran accelerated Learning dapat meningkatkan aktivitas belajar dan hasil belajar siswa. Dari data yang telah diperoleh menegaskan bahwa terjadi peningkatan jumlah siswa yang memperoleh hasil belajar dengan nilai 75 ke atas (sesuai dengan kriteria keberhasilan tindakan 80\%) pada pembelajaran pada siklus 1 terdapat 12 orang $(54,5 \%)$. Sedangkan pada siklus 2 jumlah siswa yang memperoleh nilai di atas 75 meningkat menjadi 19 orang $(86,4 \%)$.

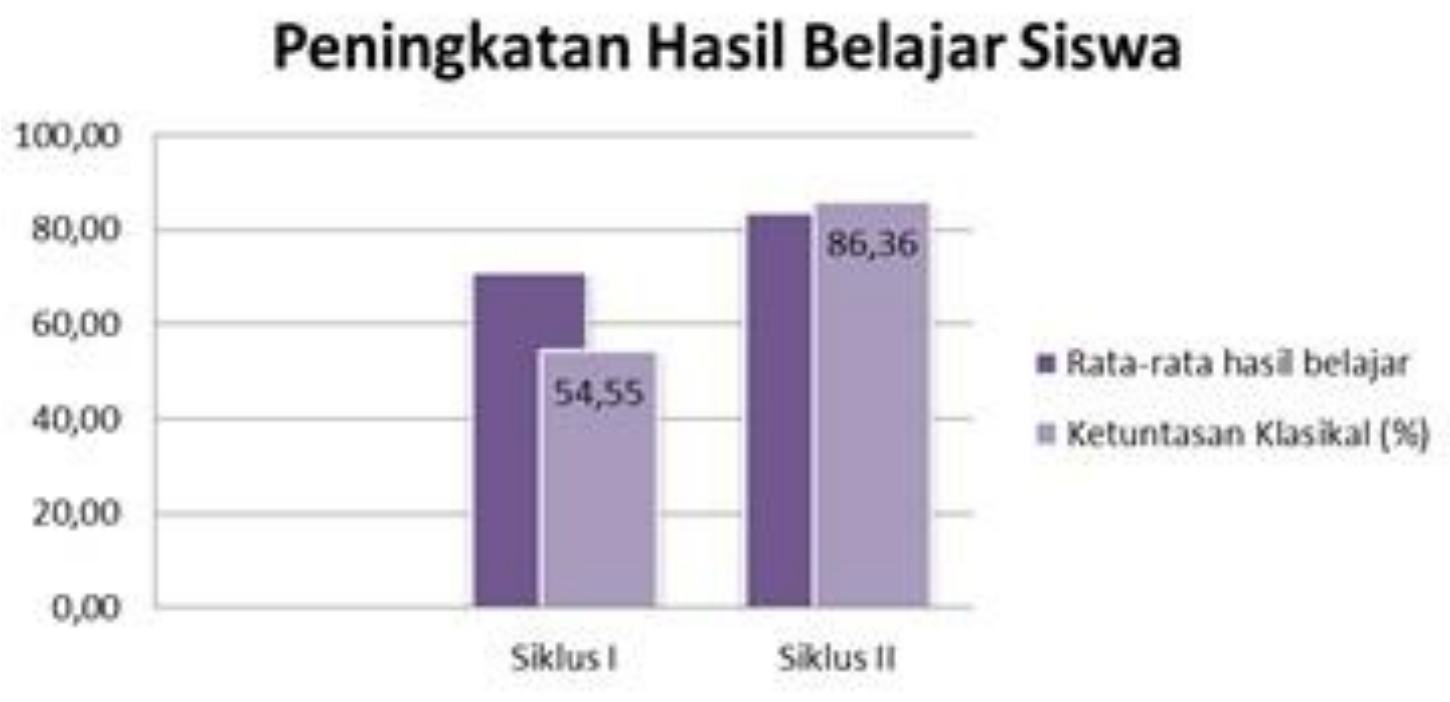

Gambar 3. Peningkatan Hasil Belajar Siswa

\section{Simpulan}

Terdapat peningkatan yang positif terhadap aktivitas belajar siswa setelah menggunakan model pembelajaran accelerated learning. Hal ini didasari oleh perolehan hasil analisis observasi yang dilakukan selama proses pembelajaran. Hasil analisis data pengamatan/observasi menunjukkan bahwa terjadi penigkatan dari siklus satu ke siklus dua setelah melakukan tindakan dengan menggunakan model pembelajaran accelerated learning. Hasil analisis data menunjukkan persentase aktivitas siswa pada siklus satu sebesar pada kategori cukup, sedangkan pada siklus dua menunjukkan persentase sebesar pada kategori baik sekali. Penggunaan model Accelerated Learning membuat siswa merasakan senangnya belajar, menumbuhkan minat, membentuk keterhubungan atau kepedulian satu sama lain dan partisipasi aktif, menumbuhkan kreatifitas, membentuk pengertian dan cara menumbuhkan penghayatan pada siswa. Dengan 
demikian, faktor-faktor yang dapat mempengaruhi hasil belajar siswa menjadi rendah dapat diminimalisir sehingga hasil belajar siswa tersebut secara tidak langsung dapat meningkat dengan menggunakan model pembelajaran ini.

\section{Daftar Pustaka}

Bahari, N. K. I., Darsana, I. W., \& Putra, D. K. N. S. (2018). Pengaruh Model Discovery Learning Berbantuan Media Lingkungan Alam Sekitar terhadap Hasil Belajar IPA. Jurnal IImiah Sekolah Dasar, 2(2), 103. https://doi.org/10.23887/jisd.v2i2.15488

Cahyani, M., Dantes, N., \& Riastini, P. N. (2015). Penerapan Model Pembelajaran Accelerated Learning Dalam Pola Lesson Study Untuk Meningkatkan Hasil Belajar Matematikapada Siswa Kelas lii Semester I Di Sdn 3 Sambangan Kecamatan Sukasada Tahun Ajaran 2014 / 2015 Universitas Pendidikan Ganesha.

Kusuma, A. P., \& Ramadoni, N. K. R. (2020). The Application of the Accelerated Learning Cycle, Brain-based Learning Model, and Direct Instruction Model toward Mathematical Reasoning in Terms of Mathematical Communication. Jurnal Pendidikan Matematika, 11(1), 21-28. https://doi.org/https://www.researchgate.net/publication/346752624_The_Applicati on_of_the_Accelerated_Learning_Cycle_Brain-

based_Learning_Model_and_Direct_Instruction_Model_toward_Mathematical_Re asoning_in_Terms_of_Mathematical_Communication/link/5fd048cd45851568d $14 \mathrm{~d}$ 8696/download

Lestiawan, F., \& Johan, A. B. (2018). Penerapan Metode Pembelajaran Example Non Example Untuk Meningkatkan Keaktifan Dan Hasil Belajar Dasar-dasar Pemesinan. Taman Vokasi, 6(1), 98-106.

Putra, R. W. Y., \& Linda, S. (2016). Pembelajaran Matematika dengan Metode Accelerated Learning untuk Meningkatkan Kemampuan Penalaran Adaptif. A/Jabar: Jurnal Pendidikan Matematika, 7(2), 211-220. https://doi.org/https://doi.org/10.24042/ajpm.v7i2.36

Rahmat, A., Andrizal, \& Basri, I. Y. (2018). Pengaruh metode pembelajaran problem based learning terhadap hasil belajar mata pelajaran teknologi dasar otomotif siswa smk negeri 1 padang. Automotive Engineering Education Journals, 1(1). https://doi.org/http://ejournal.unp.ac.id/students/index.php/poto/article/view/3430/2 364

Sawawa, D., Solehudin, A., \& Sabri, S. (2018). Pengaruh Faktor Internal Dan Eksternal Siswa Terhadap Hasil Belajar Pada Mata Pelajaran Mekanika Teknik Dan Elemen Mesin. Journal of Mechanical Engineering Education, 5(1), 21. https://doi.org/10.17509/jmee.v5i1.12615

Siregar, R. H. (2019). Model Pembelajaran Accelerated Learning Cycle Terhadap Self Concept Matematis Siswa. TAZKIR:Jurnal Penelitian IImu-IImu Sosial Dan Keislaman, 05(2), 291-308.

Subeni, L. (2018). Penerapan Konsep Accelerated Teaching Model MASTER untuk Meningkatkan Motivasi Belajar Fisika Siswa Kelas X SMA Negeri 4 Luwu. Jurnal Pendidikan Fisika-Journal of Physics Education, 6(2), 189-202. https://doi.org/https://journal.unismuh.ac.id/index.php/jpf/article/view/1291/1151.

Sucipto, D., Putra, M., Sugiyarti, S., \& Putra, Y. Y. (2018). Pengaruh Model Accelerated Learning Cycle terhadap Kemampuan Pemecahan Masalah Matematika Materi Bilangan Bulat The Influence of Accelerated Learning Cycle Model on Mathematic Problem Solving of Integers Material. 1(1), 12-23. https://doi.org/https://doi.org/10.31540/jmse.v1i1.136 
Syamsi, A. M., Rochmand, C., \& Rusnayati, H. (2016). Penerapan Model Pembelajaran Accelerated Learning Untuk Meningkatkan Kemampuan Literasi Sains. Journal of Teaching and Learning Physics, 1(1), 1-6. https://doi.org/https://doi.org/10.15575/jotalp.v1i1.3406

Wardana, S., \& Sagoro, E. M. (2019). Implementasi Gamifikasi Berbantu Media Kahoot Untuk Meningkatkan Aktivitas Belajar, Motivasi Belajar, Dan Hasil Belajar Jurnal Penyesuaian Siswa Kelas X Akuntansi 3 Di Smk Koperasi Yogyakarta Tahun Ajaran 2018/2019. Jurnal Pendidikan Akuntansi Indonesia, 17(2), 46-57. https://doi.org/10.21831/jpai.v17i2.28693

Widani, N. K. T., Sudana, D. N., \& Agustiana, I. G. A. T. (2019). Pengaruh Model Pembelajaran Inkuiri Terbimbing Terhadap Hasil Belajar Ipa Dan Sikap IImiah Pada Siswa Kelas V Sd Gugus I Kecamatan Nusa Penida. Journal of Education Technology, 3(1), 15-21.

Witari, I. G. A., Mahadewi, L. P. P., \& Rati, N. W. (2018). Pengaruh Model Pembelajaran Kooperatif Tipe Numbered Head Together terhadap Hasil Belajar IPA Siswa Kelas IV. Journal PGSD Universitas Pendidikan Ganesha Jurusan PGSD, 4(1). 